\title{
INFLUENCERS' ENGAGEMENT IN A BRAND COMMUNICATION: LATVIA AND CYPRUS CASES
}

\author{
George Antoniades ${ }^{1}$, Dace Briede ${ }^{2}$, Marta Kontina ${ }^{3}$, Inga Milevica ${ }^{4}$, Vita Stige- \\ Skuskovnika ${ }^{5}$ \\ ${ }^{1}$ CTL Eurocollege,Limassol, Cyprus, georgean@ctleuro.ac.cy \\ ${ }^{2}$ Alberta College, Riga, Latvia, dace.briede@gmail.com \\ ${ }^{3}$ Alberta College, Riga, Latvia, marta.kontina@gmail.com \\ ${ }^{4}$ Alberta College, Riga, Latvia, inga.milevica@gmail.com \\ ${ }^{5}$ Alberta College, Riga, Latvia, vita.stige@gmail.com
}

\begin{abstract}
Research purpose. Social networks have become an integral part of life, making social media one of the most significant advertising platforms, which, according to many experts and scientists, is one of the most effective brand communication techniques. According to Google's data (Think with Google, 2018), before the purchase, shoppers like to address real people, which they think could be trusted. Branding with influencers is a new way of promoting products and services. It has also recently been a much sought research topic both in terms of studying the brand communication and the influencer phenomenon. This comparative study explores the involvement of influencers in brand communication. The aim of the research is to analyse the involvement of Latvian and Cypriot influencers in brand communication, its features in theoretical and practical aspects.
\end{abstract}

Design/Methodology/Approach. The research methods used were content analysis of Latvian and Cypriot influencer accounts, comparative analysis, literature analysis and graphical method.

Findings. Within the theoretical framework of the study, a review of literature has been carried out on influencers' involvement in brand communication, with particular focus on research in Cyprus and Latvia, as well as influencer typologies, communication features and current aspects of the research. The practical part of the research explores the demographic portrait of the Cypriot and Latvian influencers, the most important features of brand communication, paying particular attention to the principles of choosing influencers' social networking platforms and brand communication labels in their communication - hashtags (\#Reklāma, \#Ad, \#Sadarbība, \#Paidpartnership, \#Apmaksātasadarbība), as well as tendencies and regularities in their use or non-use.

Originality/Value/Practical implications. The results of the study can be used by brand communication researchers, as well as by marketing and public relations professionals, to identify the key features of communication of influencers, including in comparative terms, and to select optimal tactics for collaboration with influencers.

Keywords: Influencer; Brand Communication; Marketing Communication; Advertising; Social Media.

JEL codes: M3.

\section{Introduction}

Social networks have become an integral part of life, making social media one of the most significant advertising platforms, which, according to many experts and scientists, is one of the most effective brand communication techniques. According to Google's data (Think with Google, 2018), before the purchase, shoppers like to address real people, which they think could be trusted. Thereby the representation of the brand exceeds much further than just a symbol or logotype and is closely related to clients' emotions that arise in contact with the company (Mediju tilts, 2019). Branding with influencers is a new way of promoting products and services. It has also recently been a much sought research topic both in terms of studying the brand communication and the influencer phenomenon. As a result, influencer marketing 
is regarded as digital equivalent to word-of-mouth marketing. It is a type of marketing that focuses on using key leaders to drive a brand's message to the larger market (Byrne, Kearney, MacEvill, 2017).

The aim of the research is to analyse the involvement of Latvian and Cypriot influencers in brand communication, its features in theoretical and practical aspects. In order to achieve the aim of the research, the following tasks were set: (1) to research and compile information about influencers and their involvement in brand communication, paying special attention to researches from Latvia and Cyprus; (2) to analyse 108 Cypriot and 309 Latvian influencer accounts on Instagram during the period from September 2019 to December 2019, 3. To compile information on the activity of influencers' accounts in relation to brand communication in Cyprus and Latvia. The following research methods were used: content analysis of Latvian and Cyprus influencer accounts, comparative analysis, literature analysis and graphical method.

\section{Literature Review}

Influencer. According to Watts and Dodds (2007), influencers are those individuals who influence an exceptional number of their peers. Grave (2017) defined social media influencers as opinion leaders in digital social media, and these opinion leaders communicate to a mass audience. Similar definitions of influencers are also stated by other researchers, highlighting some specific characteristics. For example, Jiménez-Castillo and Sánchez-Fernández (2019) in their definition included the reasons of becoming influencer: those are people who have gathered popularity because of their expertise, authority or other reasons. They are often involved in creative work, something that is especially demanded amongst brands. Through their creative work, they can inform their audiences about the products or services of specific brands. According to Lou and Yuan (2018), influencer is someone who has a power to influence other peoples' thoughts on social media sites such as Instagram, Facebook, Twitter, YouTube and Snapchat. They also highlight some industries where the activity of influencer marketing is high healthy lifestyle, traveling, food, beauty, fashion, etc. (Lou \& Yuan, 2018).

According to Influencer Marketing Hub (2019), an influencer has two characteristics. First, the influencer has the power to affect the purchasing decisions of other people because of the authority, knowledge, position or relationship with the audience that follows him/her. Also what describes an influencer according to the same source is that he/she has a following in a particular niche.

The categorisation of influencers can vary. According to Gulberti (2019), influencers can be categorised according to the number of followers they have. When an influencer has between 10,000 and 100,000 followers, they are considered micro-influencers. The same source states that many professionals in the fashion luxury and beauty industry seek this type of influencers because of the belief that they can communicate better with their audience.

Mid-tier influencers come next with a range of 100,000-500,000 followers. The professionals who show preference to this group do so because they have more followers than micro-influencers and the communities targeted are still easy to communicate with.

Next size-related category according to Gulberti's article is mega-influencers with $0.5-2$ million followers. They are very well-known personalities and usually collaborate with multiple brands. The benefit in involving a mega-influencer is of course the fact that there is a larger audience and more communities to address to.

According to Gulberti (2019), an all-star influencer is someone with over 2 million followers. The benefit of using an all-star influencer is the fact that the advertisers get immediate impact and high reach.

According to Inflowlabs (2017), a nano-influencer is someone who has between 100 and 1000 followers on their social account; micro-influencers are generally understood to be topic experts or topic fans with follower numbers in the 1,000-10,000 range. Macro-influencers have between 10,000 and 100,000 followers and are perceived as genuine and relatable plus they add more professionalism to their content. Mega-influencers have 100,000 to millions of followers. They win when it comes to number of likes, comments and reach. However, their engagement rate is around only $2-5 \%$ of their total followers (Inflowlabs, 2017). 
Categorisation of influencers can then be extended to the occupation, or expertise of the influencer. Some of these categories of influencers can be movie stars, activists, reality TV stars, journalists and so on.

Social influencers and their role in brand communication. Brand communication, being integral part of brand management, informs interested parties about the products, services, values and so on. Interested parties can be employees of the company, investors, sponsors or buyers (Smith, 2018). The popularity of influencer marketing is growing every year. A recent report stated that, in 2018, 39\% of marketers had plans to increase their budget for influencer marketing and 19\% of marketers intended to spend more than $\$ 100,000$ per campaign (Bevilacqua and Del Giudice, 2018).

Many of today's companies have turned to social media influencers in order to have a review for their products. They often pay them to review their products in attempt to create awareness (Cramer, 2015).

This is to be expected because studies have shown that people make their purchase decisions on either emotion or rationality (Grundey, 2008). Having this in mind, a good combination of both is a favourite person who would stimulate the emotion part, and the rationality part would be stimulated through the thought that because it is demonstrated by this person I favour, then it must be practical.

Studies have also shown that consumers rely heavily on the information they receive from people in their own network when they want to buy something (Sadovykh, Sundaram \& Piramuthu, 2015).

The moment an influencer is attempting to send a message about the brand, he/she is contributing to the understanding of this message to those users who did not directly get it from the brand itself (Araujo et al., 2017). So it is essential for brands to use the influencer as part of their digital marketing communication campaign and, more expediently, in their integrated marketing communication efforts. In other research findings, we see that these days, people do not rely on traditional advertisement to make a purchase decision. People research opinions, and they collect information before purchasing. Consumers have more confidence in the opinion of influencers than traditional advertisers (Roelens, et al., 2016).

Schau and Gilly (2003) mentioned that influencers become more powerful in effecting others and are more accessible than the major known people because they share personal every day scenes of their lives, and they interact with their followers easier.

For companies, the important thing is to find a suitable influencer. One way to 'measure' the suitability is the number of followers the person has (Colliander \& Dahlén, 2011). It is a logical measurement because according to the product and budget a brand has can find a suitable influencer. Then a brand must examine the effectiveness of specific influencer. According to Godes and Mayzlin (2004), one point that would determine the effectiveness of an influencer is his/her relationship with the brand itself and the other point is the credibility of the influencer. This seems to make sense as well. It only makes sense if a fashion-related personality will write reviews and commends on fashion-related brands rather than a science-related personality.

The rise of social media has opened up a new channel for brands to connect with consumers more directly and more organically. Social media influencers promote brands through their personal lives, making them relatable to the average consumer. People learn from example, and influencers lead by example for those who 'follow' them (Glucksman, 2017). Influencers truly serve as the ultimate connection between a brand and a consumer. Through their candidness and openness with consumers, influencers have high social clout and credibility (Buyer, 2016). Where traditional marketing targeted mostly mass audiences, influencers have the unique ability to target niche audiences that have until now been unreachable (Ledbetter, 2017). Companies are using their resources via social media influencers in hopes that the experience that a consumer has with an influencer allows the behaviour of the influencer to be adopted, that is, copied by the consumer (Forbes, 2016). Brands want influencers promoting their products who are confident in themselves. When influencers express confidence in themselves, it also promotes confidence in the brand. This brand confidence leaves a lasting impression on followers and causes them to consider becoming a consumer of the product. From the placement of the product, to the caption, and even to the context of the scene in which the advertisement is taking place, everything is executed in a particular way to maximise brand recognition through individual personalities 
(Glucksman, 2017).

According to Woods (2016), there is a certain level of risk the advertiser is taking on when partnering with any influencer, which is why the vetting process is a long one. The possibility of an influencer creating controversy before or any time after a campaign launches is a real risk and one that must be considered when working them. Negative attention brought to the influencer can bring negative repercussions to the brand that partners with them. By partnering with an influencer, they become an extension of brand's voice, invoking consequences when something goes wrong. To minimise a portion of this risk, some agencies have set up an approval process. Also advertising agencies often go through influencer agencies who recommend influencer for a brand or campaign (Woods, 2016).

In Cyprus. Even in a small country such as Cyprus with a total population of approximately 875, 000 (Ministry of Finance Republic of Cyprus, 2019), the role of the influencer is appreciated and even honoured. In 2018, the first influencer award ceremony in Cyprus was organised by trends.com.cy in collaboration with Cal Creative Communication. The event was supported by well-known brands such as Johnnie Walker, Shark and Hilton (Trends, 2018). For the specific event, influencers were awarded in various categories, that is, top female influencer, top male influencer, top blogger and top makeup artist. For example, the top female influencer had about 55,000 followers, which is not a very high number compared to other international markets; however in Cyprus, each of her posts reaches $6 \%$ of the country's population. Influencers in Cyprus have not united in any legal association or other entity, and rules and regulations about posting correspond with general European and Cypriot laws.

In Latvia and Baltic States. According to the research carried out by advertising agency 'GolinRiga', $38 \%$ of Latvian population does not know who influencers are or they do not actively use social media networks. Majority of these respondents represent the 40-65 years age group. From those who know who influencers are and who actively use social media networks such as Instagram, YouTube and blogs, $17 \%$ have purchased a product promoted by an influencer and $27 \%$ acknowledge that they have had a strong wish to purchase a product. From the products that have been purchased after the recommendation of influencer, the most popular categories are technology devices (29\%), beauty products (24\%) and events (22\%). This survey was carried amongst economically active Latvian population aged 16-65 years (1621 persons, 52\% women, $48 \%$ men) (GolinRiga, 2018).

According to the analysis performed by Hype Auditor (company for analysis of Instagram and YouTube blogger accounts) and ordered by A. W. Olsen \& Partners communication agency, core influencers in the Baltic states are women $(62 ., 01 \%)$, of whom majority are aged between 18 and 34 years. The average engagement of the Baltic States influencers is $25 \%$ higher than the worldwide average. Users in the Baltic States are more engaged in influencers' content. Nano-influencers have the strongest connections with their audience, thus their engagement rate is higher (7.8\% both in Estonia and Latvia; $5.9 \%$ in Lithuania). Lifestyle (6.35\% ER) and Photography (5.55\% ER) are the most engaging topics on Instagram in the Baltic States followed by Travel \& Tourism (4.51\% ER), Beauty \& Fashion (4.28\% ER), Fitness \& Yoga (3.84\% ER) and so on. However, according to the analysis, more than half of Latvian influencers are scammers. The smallest number of scammers (44\%) is observed in the category of nano-influencers, that is, those users of the Instagram whose number of followers does not exceed 5,000 . The largest number of scammers is amongst those with 5,000-20,000 subscribers, namely $61 \%$. The most popular type of fraud is the purchase of followers - on an average, in the Baltics, amongst all types of influencers, $28 \%$ are noticed in this activity. Again, there are more scammers in the category from 5,000 to 20,000 subscribers: in Latvia, 38\% of bloggers have some of the followers purchased, $38.5 \%$ in Estonia and 33\% in Lithuania. Every sixth (17\%) is engaged in the purchase of comments, and every sixteenth $(6 \%)$ participate in mutual commenting groups. The research of 5,000 profiles of Baltic influencers was organised in September 2019 (Olsen A. W. \& Partners, 2019).

In 2018, 'Bloggers and Influencers Association of Latvia' was established. Its activities include counting professional influencers of Latvia that work according to professional standards - authentic followers, high-quality content and financial transparency. The association also works on educating and consulting on topics related to influencer marketing, fostering professional development of influencers and so on. The association has also developed its code of ethics (Latvijas Blogeru un influenceru asociācija, 2018). 


\section{Methodology}

During the research period from September to December 2019, 309 Latvian and 109 Cypriot influencer accounts on Instagram were analysed to monitor their activity. The accounts were chosen based on various criteria: the number of followers, influencer's activity and inclusion in the influencer's top of respective country. For the data analysis, the following information was gathered about each influencer: name, surname, Instagram username, gender, represented sector(s) and number of followers. A sample table was developed that was used by all parties involved. In addition, Latvian influencers were also analysed separately by gathering data about their post frequency (including paid content) and the usage of hashtags such as \#reklāma, \#sadarbība, \#sponsorēts, \#apmaksāts and \#ad that are suggested by Latvian authorities as examples of good practice.

\section{Results}

The results of the research show that the sectors that are the most represented on Instagram in both countries are entertainment, fashion and other creative industries. However, there are also some significant differences between the countries.

The vast majority of influencers in Cyprus have a great relation with the fashion industry, because $69.7 \%$ of them have a relationship with the fashion industry as a primary interest or as a combination with something else such as fitness, television and entertainment. Therefore, we see that micro-influencers in Cyprus are combining a number of interests rather than being 'experts' in one specific area. Top sectors of influencers in Cyprus are presented in Figure 1.



Fig. 1. Analogy of influencers' Sectors in Cyprus (created by authors)

As it can be expected, and according to the above figure, most followers will fall in the sector of Fashion in Cyprus. Even though the number of singer influencers is less than those of TV host and entertainment, they have the second largest number of followers. Singers and actors fall in the last two places when it comes to number of followers. Figure 2 shows the comparison. 




Fig. 2. Top most followed sectors in Cyprus (Source: Authors)

In Latvia, higher diversity of sectors can be observed on Instagram. In addition to creative and entertainment sectors, there are also influencers who represent sport, retail sale of clothing, hairdressing and beauty service providers, banking and others. Top 10 most followed sectors in Latvia are presented in Figure 3.

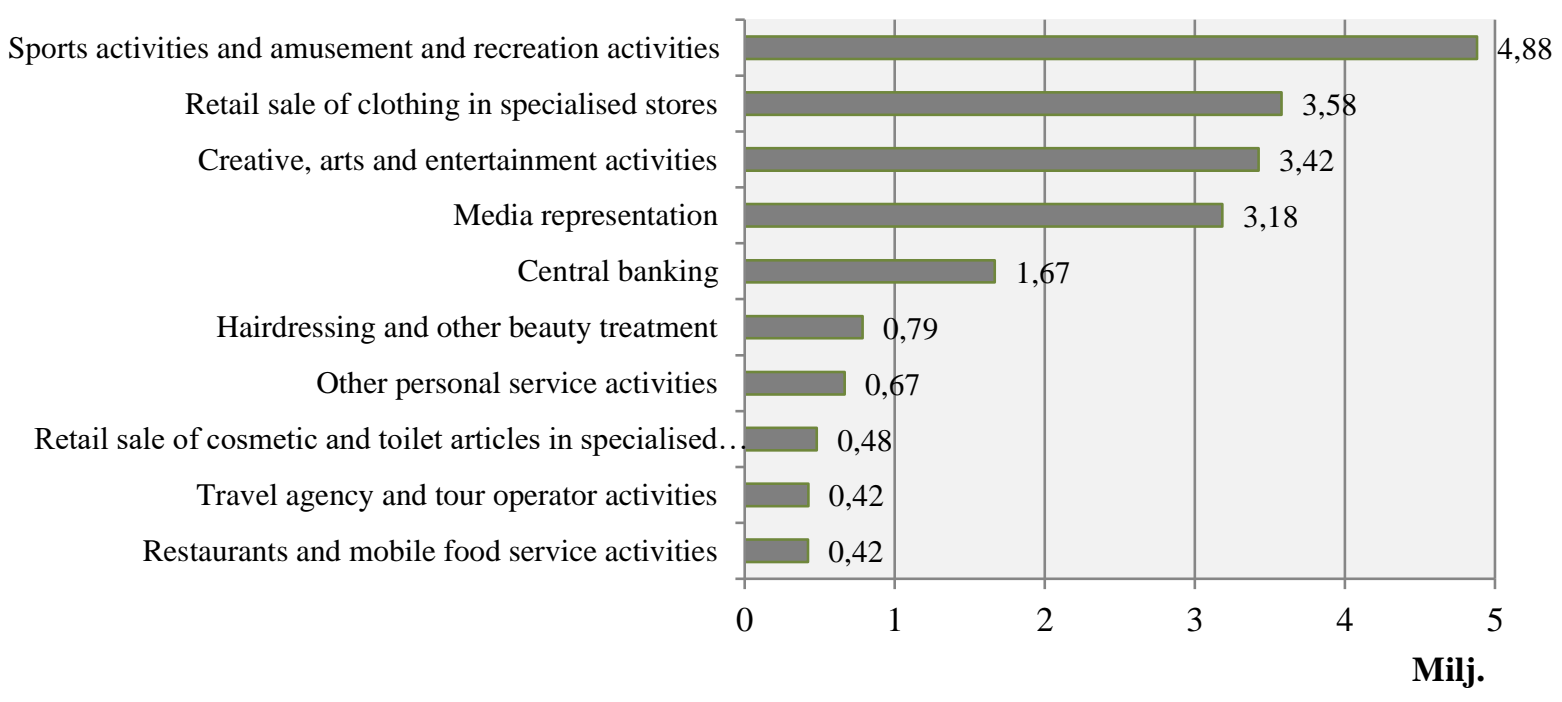

Fig. 3. Top 10 most followed sectors in Latvia (Source: Authors)

The research corresponds with other researches carried out in Latvia and Cyprus. Majority of influencers are women (76 [69.7\%] in Cyprus and 186 [60.19\%] in Latvia). A noteworthy tendency can be seen in data from Latvia - there are several joint accounts with a high number of followers such as music bands 'Prāta vētra' ('Brainstorm') and 'Singapūras satīns', sisters Karlīna and Elīza or 'Two Candies', rigainmycolours (group of people that post photos of Riga) and seeksimple (a joint lifestyle and zero waste account created by Laura Arnicāne and Andis Arnicāns).

Another significant tendency is that Latvian women influencers often represent various sectors at the same time (Fig. 3). On the other hand, Latvian male influencers have a tendency to represent exclusively one sector. There are also differences amongst the sectors represented by women and men. Top 10 
sectors represented by Latvian women are presented in Figure 4. Top 10 sectors represented by men are presented in Figure 5.

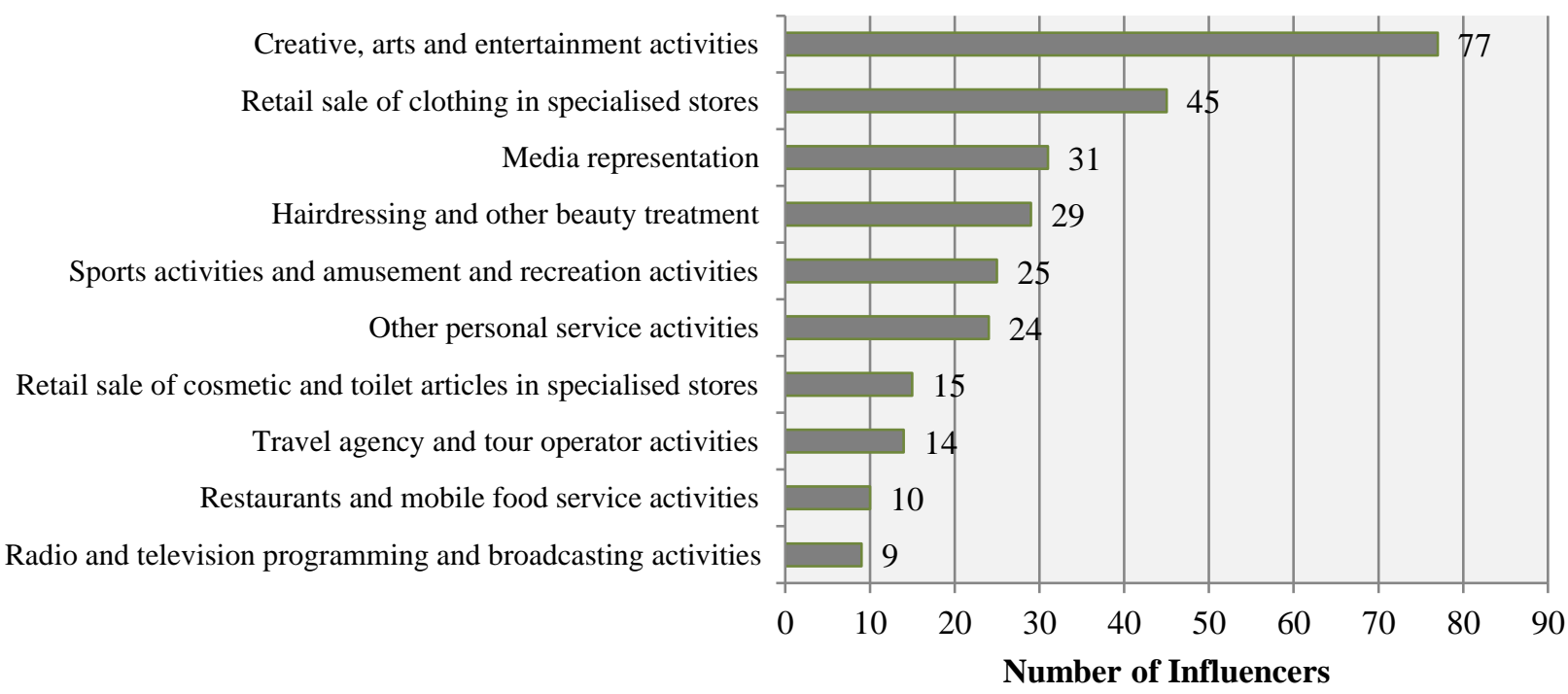

Fig. 4. Top 10 sectors amongst women Instagram influencers in Latvia (Source: Authors)

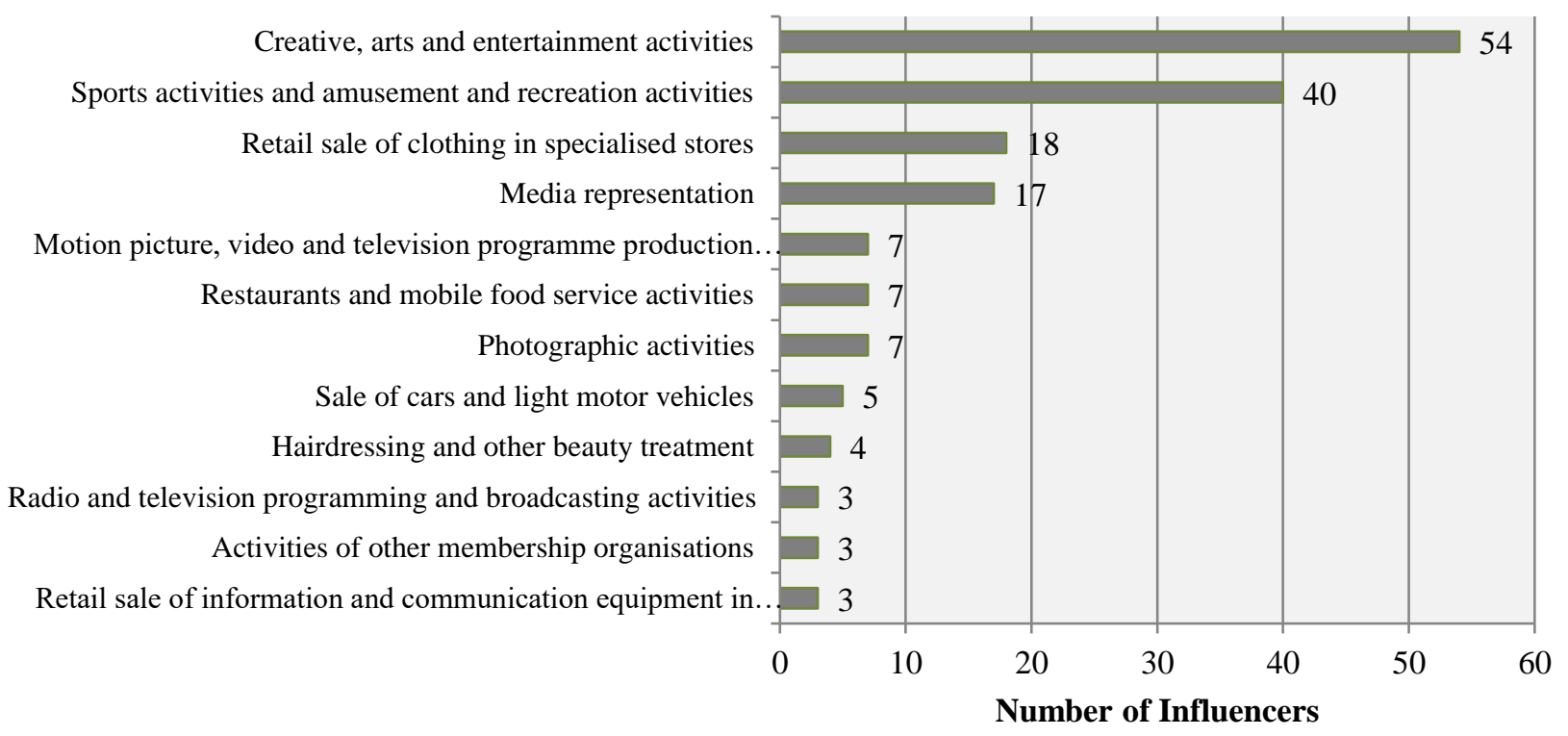

Fig. 5. Top 10 sectors amongst men Instagram influencers in Latvia (Source: Authors)

\section{Conclusions}

At this stage of the research, and according to the results we have, we see that a large number of influencers in both countries combine more than one industries in order to promote and send messages about brands. This phenomenon is more obvious in Cyprus because the market is more compact. As seen from the tables and the results, Cyprus had significantly less sectors, given the fact that influencers in categories Latvia has (e.g. sports and hairdressing etc.), could not have as many followers that would be significant enough to be measured. Hence, the intense multi-sector observation in Cyprus is limited.

Diversity of sectors in Latvia in comparison with the narrow selection of these factors in Cyprus probably has to do with the size of the two countries and may be the difference in cultures, or even 
Northern versus Southern European trends. It would be interesting to examine similar cases in future research.

It is observed that, in Latvia, most people show interest in creative arts and entertainment activities, whilst Cypriots are more concerned about fashion. This is something to be considered by marketing departments for both countries.

As seen from the results, a common observation is that both countries have high degree of interest in the clothing industry. Either for the purpose of fashion, such as the case of Cyprus, or retail sale of clothing, in the case of Latvia, which is the sector that comes the second most followed, it seems that clothing industry has some of the most significant market influencers.

This was the first phase of the long-term research that will continue in 2020. In the second phase, more attention will be paid to the content and hashtags used by the influencers. Also, other social networking platforms such as YouTube will be analysed.

\section{References}

Araujo, T., Neijens, P. \&Vliegenthart, R. (2017). Getting the word out on Twitter: the role of influential, information brokers and strong ties in building word-of-mouth for brands. International Journal of Advertising, 36(3), 496-513.

Byrne, E., Kearney, J., MacEvilly, C. (2017). The role of influencer marketing and social influencers in public health. Proceedings of the Nutrition Society, 76, 2017. [Accessed 10.01.2020]. Available from Internet: https://doi.org/10.1017/S0029665117001768

Cheung, C.M., \& Lee, M.K. (2010). A theoretical model of intentional social action in online social networks. Decision Support Systems, 49(1), 24-30.

Colliander, J. \&Dahlén, M. (2011). Following the fashionable friend: The power of social media weighing thepublicity effectiveness of blogs versus online magazines. Journal of Advertising Research, 51(1), 313-321

Cramer, T. (2015). Online Influences: The New Word-of-Mouth. EContent Information Today Inc. [Accessed 17.12.2019]. Available from Internet: http://web.a.ebscohost.com/ehost/pdfviewer/pdfviewer?vid=4\&sid=e4e0ab10-9086-4653-88e0c9d5677e7219\%40sdc-v-sessmgr03 p 4

Forbes, K. (2016). Examining the Beauty Industry's Use of Social Influencers. Elon Communications Journal, 7887. Available on internet: https://www.elon.edu/u/academics/communications/journal/wpcontent/uploads/sites/153/2017/06/08_Kristen_Forbes.pdf

Godes, D. \&Mayzlin, D. (2004). Using Online Conversations to Study Word-of-Mouth Communication. Marketing Science, 23(4), 545-560

Gräve, J.-F. (2017). Exploring the Perception of Influencers vs. Traditional Celebrities: Are Social Media Stars a New Type of Endorser? Paper presented at the 8th International Conference on Social Media \& Society, Association for Computing Machinery, July 28-30, 2017, Toronto.

GolinRiga (2018). Influenceru relevances pētījums. Baltijas influenceru mārtketinga pētījums Instagram (2019). [Accessed 16.10.2019]. Available from Internet: http://www.influenceri.lv/petijumi

Grundey, D. (2008). Experiential marketing vs. traditional marketing: Creating rational and emotional liaisons with consumers. The Romanian Economic Journal, 29(3), 133-151.

Gulberti, G. (2019). Four types of Influencers and the brand objectives you can achieve with them. Launchmetrics. [Accessed 17.12.2019] Available from Internet: https://www.launchmetrics.com/resources/blog/types-ofinfluencers

Glucksman, M. (2017). The Rise of Social Media Influencer Marketing on Lifestyle Branding: A Case Study of Lucie Fink. Elon Journal of Undergraduate Research in Communications, Vol.8, No.2, 2017 [Accessed 13.01.2020]. Available from Internet: https://www.elon.edu/u/academics/communications/journal/wpcontent/uploads/sites/153/2017/12/Fall2017Journal.pdf\#page $=77$

Hope Jensen Schau, Mary C. Gilly (2003) We Are What We Post? Self-Presentation in Personal Web Space Journal of Consumer Research, Vol. 30, No. 3. 
Influencer Marketing Hub. 2020. What is an Influencer? - Social Media Influencers Defined [Updated 2020] [Accessed 13.01.2020]. Available from Internet: https://influencermarketinghub.com/what-is-an-influencer/

Inflowlabs (2017) What are nano, micro, macro and mega influencers and why you should care. [Accessed 23.10.2019]. Available from Internet: https://inflowlabs.com/2018/01/09/nano-micro-macro-mega-influencerscare/

Jiménez-Castillo, D., Sánchez-Fernández, R. (2019). The role of digital influencers in brand recommendation: Examining their impact on engagement, expected value and purchase intention. International Journal of Information Management, 49, 366-376. [Accessed 16.10.2019]. Available from Internet: https://scihub.se/https://www.sciencedirect.com/science/article/pii/S0268401219301653

Latvijas Blogeru un influenceru asociācija (2018). Latvijas Blogeru un influenceru asociācijas uzdevumi [Accessed 16.02.2020]. Available from Internet: https://lvbia.org/contactus/

Ledbetter, E. (2017). The Change in Influencer Marketing from PR Strategy to Media Strategy. [Accessed 16.02.2020]. Available on Internet: https://blog.carusele.com/change-influencer-marketing-pr-strategy-mediastrategy

Lou, C., Yuan, S. (2018). Influencer Marketing: How Message Value and Credibility Affect Consumer Trust of Branded Content on Social Media. Journal of Interactive Advertising. [Accessed 25.10.2019]. Available from Internet: https://sci-hub.se/https://www.tandfonline.com/doi/abs/10.1080/15252019.2018.1533501

Ministry of Finance Republic of Cyprus (2019). Demographic Statistics 2018. [Accessed 17.12.2019]. Available from https://www.mof.gov.cy/mof/cystat/statistics.nsf/All/0F27BA4B99ABE197C22584BA003C9DED/\$file/Demogr aphic_Statistics-2018-EN-291119.pdf?OpenElement

Mediju tilts (2003). Zìmola veidošana. [Accessed 22.10.2019]. Available from Internet: https://www.medijutilts.lv/pakalpojumi/

Olsen A. W. \& Partners (2005). Baltijas influenceru mārtketinga pētījums Instagram (2019). [Accessed 20.12.2019]. Available from Internet: https://www.augstskola.lv/moodle/mod/resource/view.php?id=33152

Roelens, I., Baecke, P. \& Benoit, D. F. (2016). Identifying influencers in a social network: The value of real referral data. Decision Support Systems, 91, 25-36.

Sadovykh, V., Sundaram, D., \&Piramuthu, S. (2015). Do online social networks support decision-making? Decision Support Systems, 70, 15-30.

Smith, B. G., Kendall, M. C., Knighton, D., Wright, T. (2018). Rise of the Brand Ambassador: Social Stake, Corporate Social Responsibility and Influence among the Social Media Influencers. Communication Management Review, 3, 2018. [Accessed 16.10.2019]. Available from Internet: https://hrcak.srce.hr/index.php?show=clanak\&id_clanak_jezik=300662

Think with Google (2018). 3 ways digital video has upended shopping as we know it [Accessed 10.01.2020]. Available from Internet: https://www.thinkwithgoogle.com/consumer-insights/online-video-shopping/

Trends (2018). Influencer Awards 2018 [Accessed 17.12.2019]. Available from Internet: https://trends.com.cy/influencerawards/

Watts, D.J., \& Dodds, P.S. (2007). Influentials, Networks, and Public Opinion Formation. Journal of Consumer Research, 34(4), 441-458.

Woods, S. (2016). \#Sponsored: The Emergence of Influencer Marketing. University of Tennessee Honor Thesis Projects. [Accessed 16.10.2019]. Available from Internet: https://trace.tennessee.edu/cgi/viewcontent.cgi?article=3010\&context=utk_chanhonoproj 